\title{
SOCIO-DEMOGRAPHIC FACTORS OF THE DEVELOPMENT OF AGRICULTURE IN KHARKIV REGION
}

Л. М. Немець, М. О. Логвинова. СОЦІАЛЬНО-ДЕМОГРАФІЧНІ ФАКТОРИ РОЗВИТКУ СІЛЬСЬКОГО ГОСПОДАРСТВА ХАРКІВСЬКОЇ ОБЛАСТІ. У статті розглянуто фактори розвитку сільського господарства Харківської області, серед яких сочіально-демографічні займають особливе місие. До демографічних факторів належать кількість та густота населення, його віковий та статевий склад, кількість трудових ресурсів, віддаленість населених пунктів від обласного та районних иентрів тощо. Соціальні фактори включають тип земельних відносин, форми власності, рівень соціальнокультурного забезпечення. Для Харківської області характерна висока частка міського населення, велика міграційна активність населення сільської місиевості, особливо молоді, достатньо велика зайнятість у аграрному секторі, наявність кваліфікованих трудових ресурсів, які можливо задіяти у сільському господарстві, ефективна система розселення, яка формує споживчі потреби населення. Велика роль у виробництві сільськогосподарської продукиї̈ належить фермерським господарствам. Комплексний суспільно-географічний аналіз вказаних факторів дозволить уточнити галузі спеиіалізаиї сільського господарства Харківської області, а також ефективно використовувати земельні ресурси. Крім того, аналіз ключових факторів розміщення підприємств сільського господарства на регіональному рівні, дозволить виділити проблеми галузі та запропонувати заходи щчодо покращення ситуації з урахуванням конкретних соціально-географічних, демографічних та економічних особливостей того чи іншого регіону.

Ключові слова: сільське господарство, сочіально-демографічні фактори, демографічна ситуачія, зайнятість населення, сочіальна інфраструктура, спечіалізачія сільського господарства.

Л. Н. НемеИ, М. А. Логвинова. СОЦИАЛЬНО-ДЕМОГРАФИЧЕСКИЕ ФАКТОРЫ РАЗВИТИЯ СЕЛЬСКОГО ХОЗЯЙСТВА ХАРЬКОВСКОЙ ОБЛАСТИ. В статье рассмотрены факторы развития сельского хозяйства Харьковской области, среди которых соииально-демографические занимают особое место. К демографическим факторам относятся количество и плотность населения, его возрастной и половой состав, количество трудовых ресурсов, удаленность населенных пунктов от областного и районных иентров и т.д. Социальные факторы включают тип земельных отношений, формы собственности, уровень сочиально-культурного обеспечения. Для Харьковской области характерна высокая доля городского населения, большая миграционная активность населения сельской местности, особенно молодёжи, достаточно большая занятость в аграрном секторе, наличие квалифицированных трудовых ресурсов, которые возможно задействовать в сельском хозяйстве, эффективная система расселения, которая формирует потребительские нужды населения. Большая роль 8 производстве сельскохозяйственной продукиии принадлежсит фермерским хозяйствам. Комплексный общественногеографический анализ указанных факторов позволит уточнить отрасли спечииализачии сельского хозяйства Харьковской области, а также эффективно использовать земельные ресурсы. Кроме того, анализ ключевых факторов размещения предприятий сельского хозяйства на региональном уровне, позволит выделить проблемы отрасли и предложить мероприятия по улучшению ситуации с учетом конкретных социально-географических, демографических и экономических особенностей того или иного региона.

Ключевые слова: сельское хозяйство, сочиально-демографические факторы, демографическая ситуация, занятость населения, социальная инфраструктура, специализация сельского хозяйства.

Formulation of the problem. Agriculture of Kharkiv region is formed under the influence of a combination of factors: natural and geographical, economic, socio-demographic on the basis of agroclimatic, land, and water resources [6]. Sociodemographic factors are the leading factors in the development of agriculture in the region, which cover the population, its age and sex composition, labor resources, urbanization level, nature of settlement, the need for food, which affects the development of the industry in rural and suburban zones, as well as the territorial organization of agriculture [18].

Analysis of recent research and publications. Agriculture, as the main branch of the agroindustrial complex, remains one of the leading topics for research among Russian geographers and is considered in the works of V.P. Nagirna, Y.B. Oliinic, M.M. Palamarchuk, M.D. Pistun, O.I. Shabliy and others.

The factors that influence the development of agriculture in the regions of Ukraine were studied by the geographers M.D. Zayachuk, N.A. Kozlovska,
I.I. Rantz, A.M. Slashchuk, Y.S. Sosnovska. Features of the development of agriculture in Kharkiv region were studied by N.V. Dobrovolska, Y.I. Kandyba, Y.F. Kobchenko, S.V. Kostrikov and others.

It should be noted that the scientific institutions engaged in identifying the problems of agricultural development and its comprehensive research in Ukraine are the National Academy of Agrarian Sciences, Institute of Geography of the National Academy of Sciences of Ukraine, Institute of Economics and Forecasting of the National Academy of Sciences of Ukraine, regional research institutions, in particular, V.V. Dokuchaev Kharkiv National Agrarian University, V.Y. Yuryev National Academy of Sciences of Ukraine, P. Vasylenko Kharkiv National Technical University, V.N. Karazin Kharkiv National University in Kharkiv region.

The purpose of the publication is to reveal the influence of socio-demographic factors on the development of agriculture in Kharkiv region, to analyze the current demographic situation in the region, the level of social infrastructure and to propose, on 
the basis of the analysis, ways to improve the level of agricultural development in the region.

Statement of the main material. The demographic factor is determining for the development of agriculture, because the population simultaneously act as a subject of social production, the main productive force of society, and also as the consumer of the final product [5]. Therefore, the dynamics, structure and location of the population has a direct impact on the development of the industry.

Kharkiv region is characterized by a high proportion of urban population $(80.6 \%)$ and large population (2.718 million people) (Fig. 1).

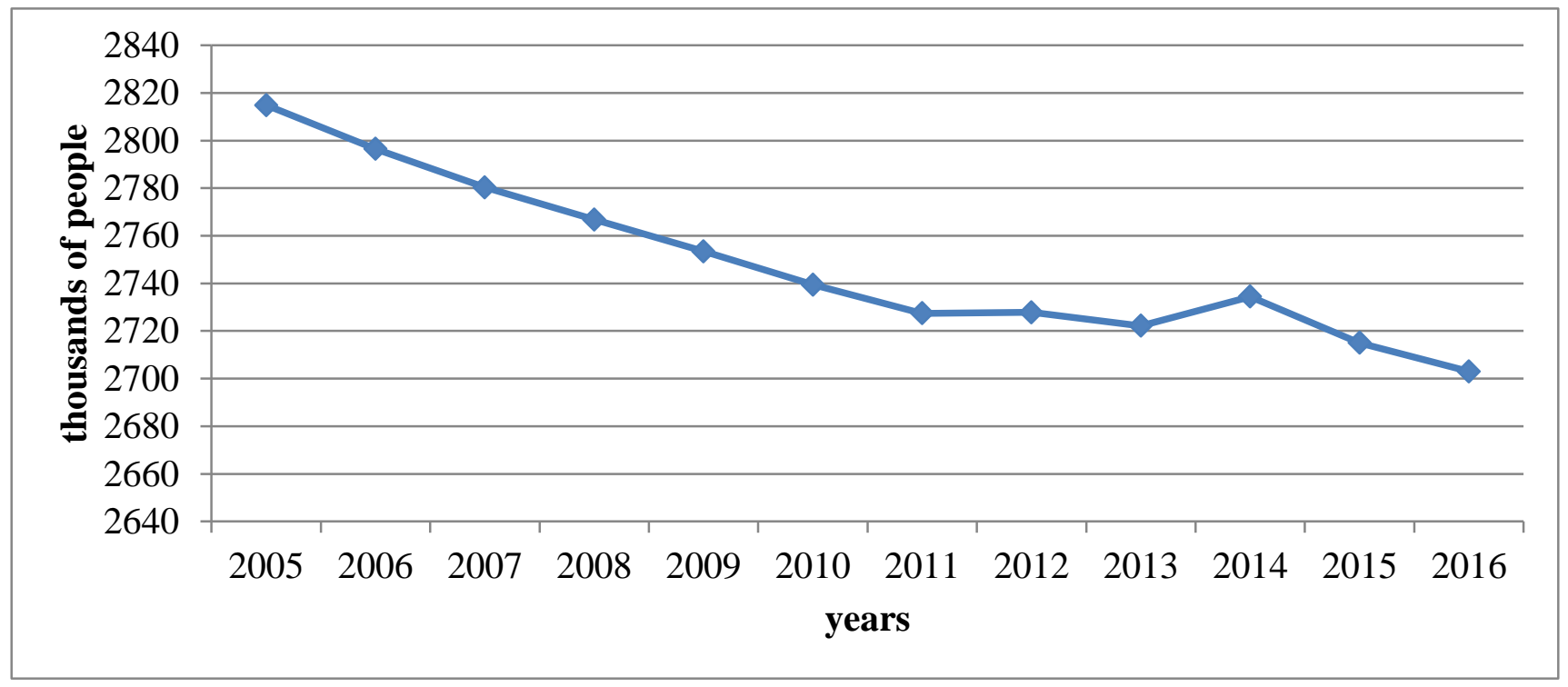

Figure 1. Dynamics of the population of Kharkiv region for the period from 2005 to 2016

(built by the authors according to the data of [19])

All administrative-territorial units of Kharkiv region are characterized by negative natural increase and a slight decrease in the population number [18]. The most rapidly declining population is in Izium ($13.8 \%$ o), Barvenkovo (-13.6\%), Kolomak (-13.2 \%o), Pervomaisky (-11.4\%o), Pechenegi (-11.4 \%o) Volchansk (-11.2 \%o), Lozova (-11.2\%) areas [9], which is due to a high proportion of the age structure of the population of the retirement age, significant mortality of the population of this age group and low fertility rates. The lowest natural decrease is observed in Kehychivka (-5.7 \%o) and Sakhnovshchina $(-5.8 \%$ ) areas [9]. The population of these areas is reduced insignificantly due to a higher birth rate and low mortality.

The age structure of the population is an important demographic factor, since its change affects the size of the population and the age composition of the employed population in agriculture, which leads to a reduction in the number of the employed and aging of labor resources [16].

Analysis of the age structure of Kharkiv region indicates that the largest number of people in the region is the population of working age $-59.5 \%$ [19]. In rural areas, there are more people whose age is higher than the able-bodied $(29.2 \%$ in comparison with the average in the region $-25.6 \%$ ), the proportion of the disabled persons is $14.6 \%$ (on average in the region $-12.7 \%$ ), the proportion of people of working age is $56.2 \%$ and in cities $-61.7 \%$. The female population prevails in the sex composition of the population $(53.7 \%$, men - 46.3\%) (Fig.2).

The number of population is also changing for the types of settlements [18]. Some urban population is constantly increasing, and rural - on the contrary, decreases (Fig. 3), due to the low attractiveness of agricultural labor for the working-age population [1]. As a consequence, a number of socio-economic problems arise in rural areas, in particular, disparities in the socio-economic development of the village in comparison with cities, an increase in unemployment, the closure of schools and libraries, which generally aggravates depressiveness of rural areas.

One of the factors in the development of agriculture is the excess of the urban population over the rural population, since the urban population is an important consumer of its products [7]. Changes in the rate of growth of the rural and urban population create a problem of production ratio of the sector, since the population of rural areas cannot fully provide urban residents with all food products, so a certain part of agricultural production is imported [16].

Under the influence of demographic factors, population density in populated areas and their size are constantly changing. In the conditions of a large proportion of the urban population in Lozova, Kharkiv, Chuguyev, Derhachi, Pervomaisky, Izium, Kupyansk areas (Fig. 4), there is a shortage of labor 


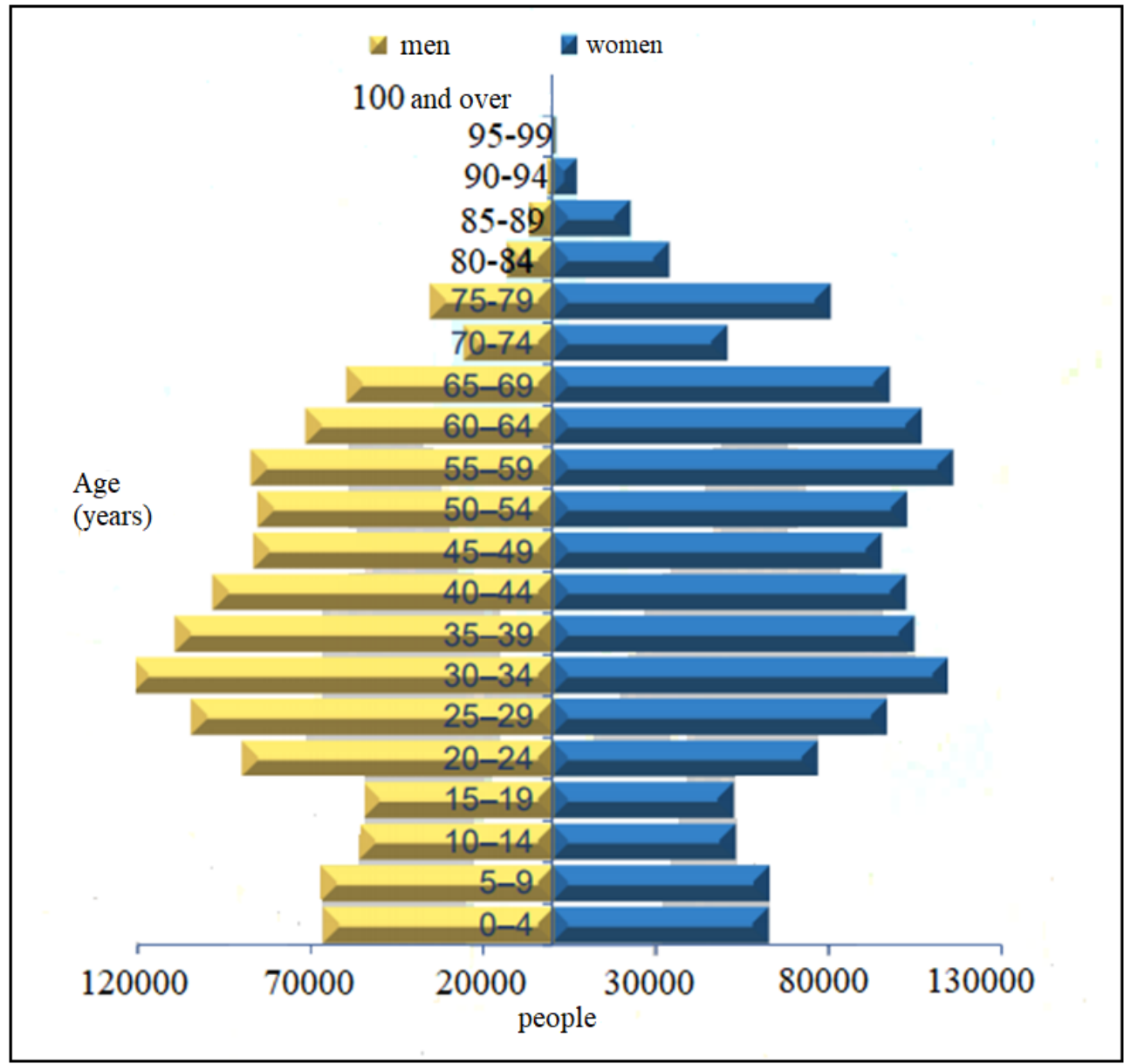

Figure 2. Sexual and age structure of the population of Kharkiv region (built by the authors according to the data of [19])

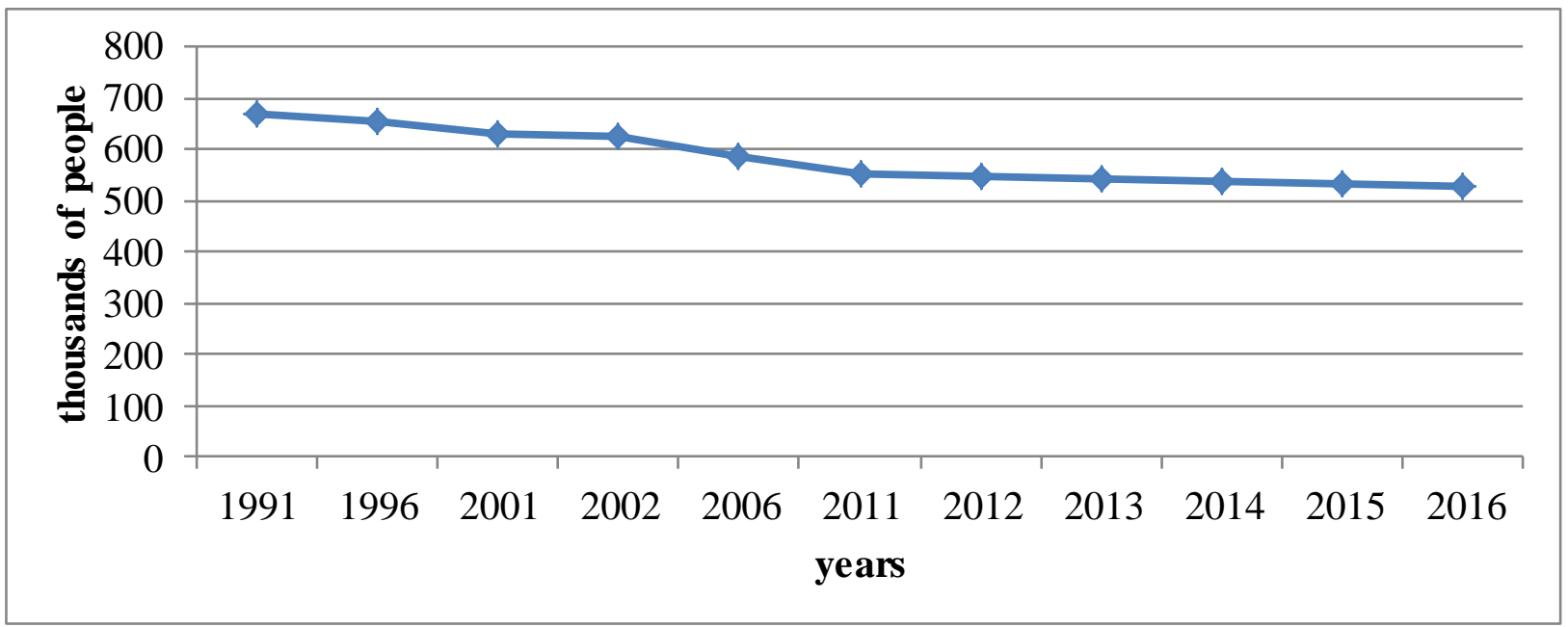

Figure 3. Dynamics of the number of rural population of Kharkiv region for the period from 1991 to 2016 (built by the authors according to the data of [8])

resources in agriculture, as a result of which there is a certain decline in agricultural land $[7,11]$. The situation in Velykyi Burluk, Barvenkovo, Bliznyuki, Borova, Dvorichna, Zachepylivka, Zolochiv, Krasnokutsk, Nova Vodolaha, Sakhnovshchina and Shevchenkovo areas is better in this respect, where the rural population is more than $60 \%[2,9]$.
Significant problems in the agricultural sector are caused by the migratory activity of the population, since there is a constant increase in the proportion of the working age population in the cities and a decrease in its part in the villages through the unattractiveness of agricultural labor [16]. This especially applies to the suburban areas of Kharkiv region Derhachi, Zmiev, Chuguyev, Kharkiv. The popula- 


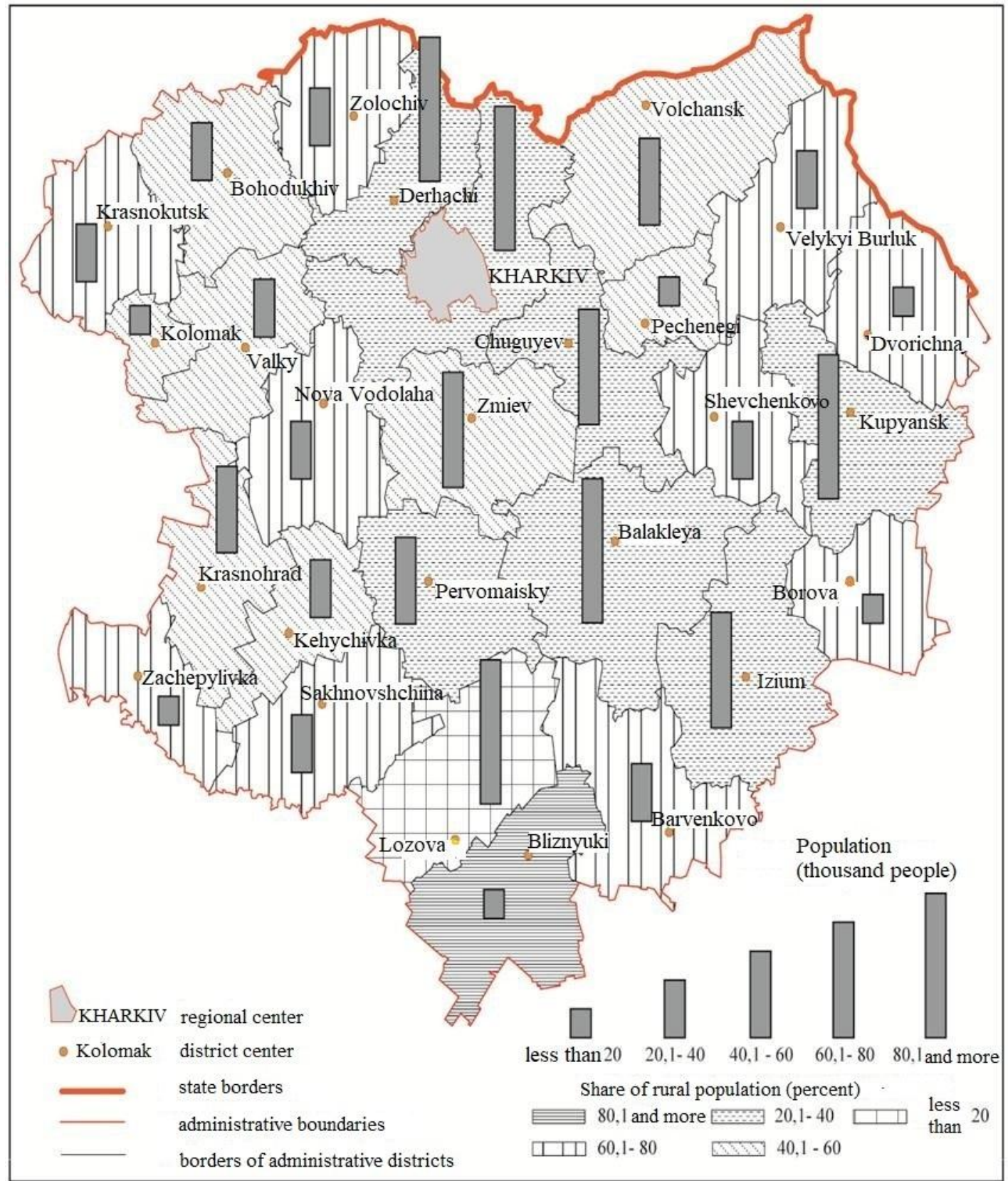

Figure 4. Accommodation of rural population in the context of districts of Kharkiv region, 2016 (built by the authors according to [9])

tion of the working age of peripheral areas Lozova, Sakhnovshchyna, Zachepylivka - is attracted to Dnipropetrovsk region.

An important factor in the development of agriculture in Kharkiv region is the availability of labor resources and their qualifications [9]. However, it is worth noting the influence of the regional center of Kharkiv on the employment of the population in agriculture [5]. In agriculture, Kharkiv region employs $10.3 \%$ of the population (Fig. 5), and this part is constantly declining, due to unrewarding agricultural work, development of private entrepreneurship, the closure of a number of farms and state agricultural enterprises [9].

A large number of the rural population, especially in the suburbs, is engaged in own farms, pro- ducing 39\% of the region's agricultural output. As part of the economically active population of rural areas, the highest unemployment rate is typical for the population aged 16-35 years. The reasons for this are the seasonality of agricultural work, reduction in the number of agricultural enterprises, low qualification of labor resources, absence among them of specialists with agrarian education, low wages in the agricultural sector $[1,16]$.

An important indicator of the economically active population is the entrepreneurial activity of the population - the number of persons who are entrepreneurs in a certain branch of the economy. In our case, the index of entrepreneurial activity in agriculture is determined by the ratio of farmers and private entrepreneurs to the economically active population 


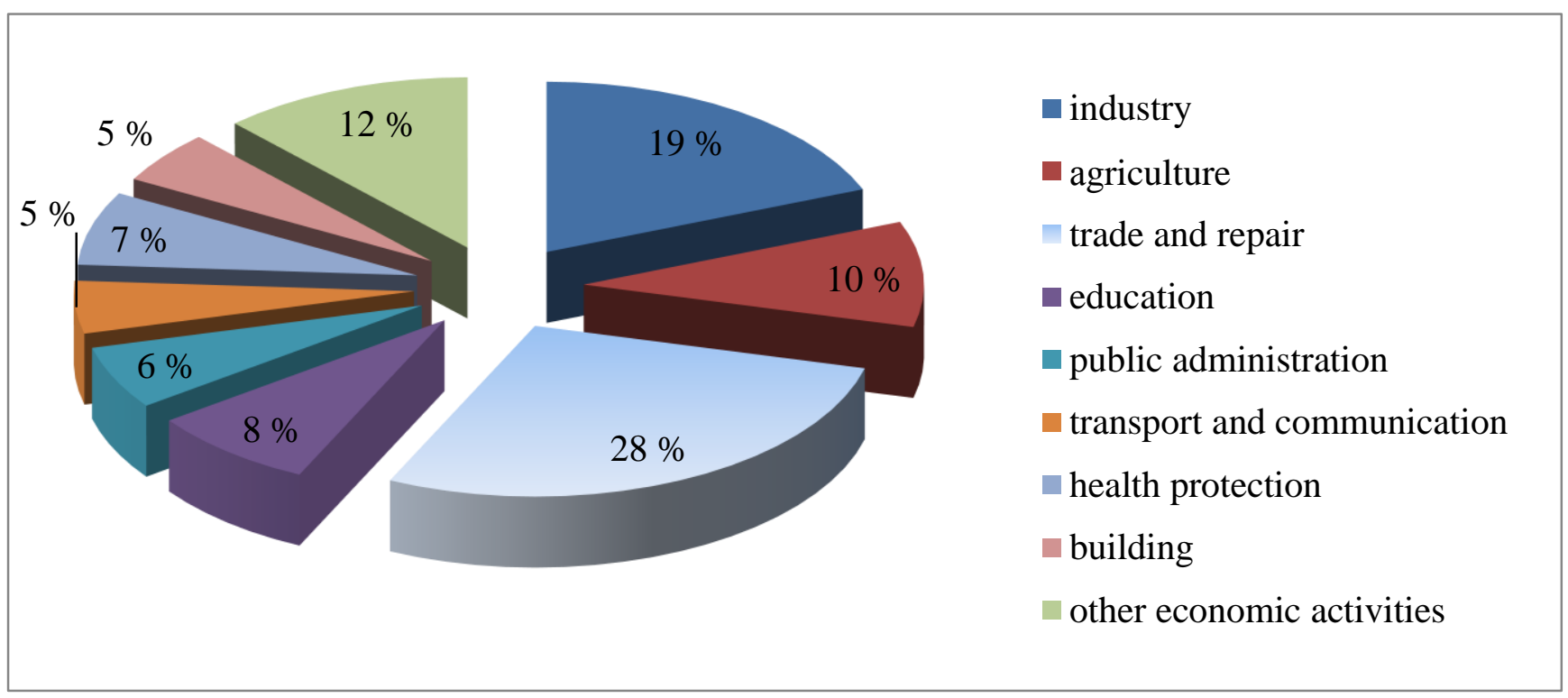

Figure 5. The employment structure of the population of Kharkiv region for the branches of the economy for 2016 (built by the authors according to the data of [19])

[16]. In Kharkiv region this indicator is $1.9 \%$ [14].

The system of settlement, formation and development of suburbs is a factor in the territorial organization of agriculture, formation of its suburban specialization [10]. The average population of rural settlements in Kharkiv region is 584 people. In the density of the rural population, intraregional differences were determined: from 9.4 people $/ \mathrm{km}^{2}$ in Barvenkovo district to 44.1 people $/ \mathrm{km}^{2}$ in Kharkiv region. The highest density of the rural population in the northern regions close to the regional center is Derhachi (30.4 people $/ \mathrm{km}^{2}$ ), Zmiev (28.2 persons $/ \mathrm{km}^{2}$ ), and Krasnohrad (24.1 persons $/ \mathrm{km}^{2}$ ) areas, due to favorable geographical position (at the intersection of transport routes) [9].

The rate of growth in prices for agricultural products lags far behind the rate of change in prices for industrial products, since they are limited to the purchasing power of the population, which often leads to a disparity in prices. The main factor that determines the purchasing power of the population is the level of its income, which varies considerably in the territory of Kharkiv region. The highest salary is in Balakleya (4763 UAH), Krasnohrad (4498 UAH), Pervomaisky (4084 UAH) districts. The lowest wages are received by residents of Zachepylivka (2466 UAH), Krasnokutsk (2613 UAH), Blyznyuky (2641 UAH), Kehychivka (2680 UAH) districts [9].

The level of wages in agriculture is significantly lower than in other industries, which is due to low efficiency of most agricultural enterprises, disparity of prices, low motivation to work. Thus, low wages in agriculture indicate a decrease in the attractiveness of the industry [13].

An important socio-geographical factor in the development of agriculture is consumer needs of the population, which stimulate the development of the industry and affect the volume of agricultural production [11].

Social factors of agricultural development include the type of land relations, land ownership forms, the level of social security and cultural and consumer services [7]. The type of land relations characterizes the relations between state authorities, local governments, agricultural enterprises, subjects of ownership, use of land, such as state regulation of land relations [4].

In modern conditions of a new economic system formation it is obvious that agriculture needs radical reforms. The old forms of ownership (state and cooperative) can no longer provide the population with the necessary products more effectively. New forms of ownership began to appear, such as: joint-stock, private and farming companies [3].

A large share in the production of agricultural products in Kharkiv region belongs to farms [8]. As of January 1, 2017, their number is 1267 , which is $64 \%$ of the total number of agricultural enterprises [14]. The increase in the share of farms in the territory of Kharkiv region is explained by the simplicity of their creation and by the relatively narrow specialization of activities, since almost all of them work in the crop sector.

The level of social infrastructure provision in rural settlements is assessed by the availability of facilities for residents of peripheral settlements, qualitative and quantitative indicators of these facilities. One of the indicators of the active functioning of the terrain is the frequency of connections between the peripheral population and the district centers. Proximity to the regional or district (area), available road and rail connections between the vil- 
lage and the city provides ways to sell agricultural products and motivates the rural population to engage in agriculture [16].

Conclusions. Socio-demographic factors determine to a large extent the level of agriculture development in Kharkiv region. Availability of free manpower, a large number of urban residents, as consumers of agricultural products, an increase in the overall consumer needs of the population form the conditions for the development of suburban types of farms. However, the efficiency of agriculture can only be improved if there is an integrated approach to the use of all factors of its development, identifying problems, opportunities for development, changing existing specialization in certain areas and the like. Socio-geographical research based on socio-demographic factors will largely solve the noted problems.

\section{References}

1. Греков, С. А. Географічні особливості сільськогосподарського виробництва в особистих селянських господарствах Чернівеиької області [Текст] : автореф. дис. на здобуття наук. ступеня канд. геогр. наук : спеи. 11.00 .02 «Економічна і соиіальна географія» / С. А. Греков. - Чернівиі, 2007. - 19 c.

2. Добровольська, Н. В. Формування екологічно збалансованого землеробства Харківської області: суспільногеографічний підхід [Текст] : монографія / Н. В. Добровольська, С. В. Костріков. - Х. : ХНУ імені В. Н. Каразіна, 2016. - 276 c.

3. Заячук, М. Д. Формування та геопросторова організація фермерства Украӥни (теорія та практика суспільно-географічного дослідження) [Текст] : автореф. дис. на здобуття наук. ступеня д-ра геогр. наук : спеи. 11.00 .02 «Економічна і соиіальна географія» / М. Д. Заячук. - К., 2016. - 40 с.

4. Земельний кодекс Украӥни [Електронний ресурс]. - Режим доступа : http://zakon5.rada.gov.ua/laws /show/2768-14

5. Козловська, Н. А. Розвиток сільського господарства Київської області у контексті впливу столичного міста [Текст] : / Н. А. Козловська // Украӥнський географічний журнал. - К.: Інститут географії НАН Украӥни. 2015. - Bun. . - C. 50-58.

6. Кобченко, Ю. Ф. Вплив погодних факторів на формування урожаю зернових культур у Харківській області [Текст] : / Ю. Ф. Кобченко, О. Ю. Кобченко, В. А. Резуненко // Вісник Харківського начіонального університету імені В. Н. Каразіна, Серія «Геологія. Географія. Екологія». - Х.: Харківський національний університет імені В. Н. Каразіна. - 2014. - Вип. 40 (1098). - С. $86-91$.

7. Крючков, В.Г. Территориальная организация сельского хозяйства (Проблемь и методы экономикогеографических исследований) [Текст] : монография / В. Г. Крючков. - М. : Мысль, 1978. - 268 с.

8. Кулєшова, Г. О. Територіальні особливості розвитку фермерського господарства в Харківській області як форми малого підприємництва [Текст] / Г. О. Кулєшова // Часопис сочіально-економічної географії: Міжрегіональний збірник наукових пращь. - Х.: Харківський національний університет імені В. Н. Каразіна. - 2012. - Bun. 13 (2). - C. 178-184.

9. Міста та райони Харківської області у 2016 рочі [Текст] : статистичний щзорічник / [за ред. О. Г. Мамонтової]. - Х. : Головне управління статистики у Харківській області, 2017. - 324 с.

10. Нємець, Л. М. Територіальні та часові особливості розвитку рослиннищтва Харківської області [Текст] / Л. М. Нємець, В. Ф. Ліхван // Часопис сочіально-економічної географії: Міжрегіональний збірник наукових працьь. Х. : Харківський національний університет імені В. Н. Каразіна. - 2012. - Вип. 12 (1). - С. 132-137.

11. Паньків, 3. П. Земельні ресурси: навчальний посібник [Текст] / 3. П. Паньків. - Львів : Видавничий иентр ЛНУ імені Івана Франка, 2008. - 272 с.

12. Про фермерське господарство [Текст] : Закон Украӥни зі змінами від 31.03.2016 № 45 [Електронний реcypc]. - Режим доступа : http://zakon1.rada.gov.ua/laws/

13. Ранияя, I. I. Територіальна організаичія агробізнесу регіону (на матеріалах Львівської області) [Текст] : автореф. дис. на здобуття наук. ступеня канд. геогр. наук : спеи. 11.00 .02 «Економічна і соиіальна географія» / I. I. Рания. - Львів, 2005. - С. 5 -7.

14. Сільське господарство Харківської області у 2015 роияі [Текст] : статистичний щзорічник / [за загальною редакцією К. П. Воловікової]. - Х.: Головне управління статистики у Харківській області, 2016. - 153 с.

15. Слашук, А.М. Географічні умови та фактори формування i розвитку агробізнесу Волинської області [Текст] / А. М. Слащук, Я. С. Лижник // Природа Західного Полісся та прилеглих територій : зб. наук. праць. - Луиььк : ВНУ ім. Лесі Українки. - 2011. - Вип. 8. - С. 64-68.

16. Сосницька, Я. С. Сучасні трансформачійні прочеси сільськогосподарського виробниитва (на прикладі Волинської області) [Текст] : автореф. дис. на здобуття наук. ступеня канд. геогр. наук : спец. 11.00 .02 «Економічна і сочіальна географія» / Я. С. Соснищька. - Чернівці, 2015. - 20 c.

17. Стратегія розвитку Харківської області на період до 2020 року [Текст] // Харківська обласна державна адміністрація Електронний ресурс]. - Режим доступа: http://old.kharkivoda.gov.ua/documents/ 16203/1088.pdf

18. Топчієв, О. Г. Суспільно-географічні дослідження: методологія, методи, методики [Текст] : навчальний посібник / О. Г. Топчієв. - Одеса: Астропринт, 2005. - 632 c.

19. Харківська область у 2016 роичі [Текст] : статистичний щзорічник / [під ред. О. Г. Мамонтової. - Х.: Головне управління статистики у Харківській області, 2017. - 535 с. 